\title{
A Review of Brand Valuation Method
}

\author{
Jiangwen Huang \\ Department of Marketing, Management School, Jinan University, Guangzhou, China \\ Email: hjw2008040126@163.com
}

Received 17 January 2015; accepted 2 February 2015; published 4 February 2015

Copyright (C) 2015 by authors and Scientific Research Publishing Inc.

This work is licensed under the Creative Commons Attribution International License (CC BY).

http://creativecommons.org/licenses/by/4.0/

(c) (i) Open Access

\begin{abstract}
The method of brand value evaluation has become an important topic as the concern of practical and theoretical circles since the 1980s. This paper analyses dimensions of brand value and sorts out the related research achievements of brand value evaluation method from asset perspective, customer perspective and a comprehensive perspective. Then the paper points out its important implications for the practice of brand valuation of Chinese enterprises.
\end{abstract}

\section{Keywords}

Brand Value, Brand Valuation, Evaluation Method

\section{Introduction}

Brand value is an important concept in business practice. In the 1980s, with the rise of mergers and acquisitions boom among enterprises, brand value evaluation attracted the attention of the business community, and became the subject widely concerned by the theoretical circle. Scholars take the studies of brand value evaluation based on principles of objectivity, measurability and perspectiveness. However, due to the differences of research purpose and personal background, scholars explain the brand value from different angles and suggest different evaluation methods [1]; therefore, the theoretical circle has not yet formed a unified view of brand value evaluation method.

The object of this study is to clarify the method of brand value evaluation and provide references for Chinese corporates. The paper is organised as follows. Following this introduction, it explains the dimensions of brand value. And then it provides an overview of the literature related to the method of brand valuation. Finally, the enlightenment to brand value evaluation practice of Chinese enterprise is discussed.

\section{The Dimension of Brand Value}

Combining the existing related literatures, brand value can be understood from three dimensions. To begin with, brand consultant Alexander Biel points out brand value has a close tie to Finance, reflecting the brand's value in 
the financial. Esteban-Bravo and Lado [2] indicated that brand value is the added value of brand in the financial. Hence, brand value is the cash flow brought to products or services by brand. On this basis, the CEO of UK Interbrand company Michael Birkin said, similar to other economic assets value, brand value reflects the present value of all the equity in the future [3]. Therefore, brand value can be interpreted as the financial benefit for enterprise created by brand as an asset.

Secondly, consulting firm Market Facts considered brand value is whether people continue to buy the brand's product or service, which means brand value has a very close relationship with customer's brand loyalty [4]. The Brand Value Committee agreed with this point of view, noting that brand value is a unique commitment to the customer providing by brand, which is worthy to own and trust [5]. According to this, brand value can be understood from the perspective of the customer. The stronger the relationship between the customer and the brand, the higher brand value.

Thirdly, some scholars defined brand value from a comprehensive perspective including both the asset and customer. Brand pioneer Donizlaff pointed out that brand value are those factors when the customer contacts the brand image, to some extent, that have an impact on customer's positive and negative values, and these factors have a significant economic value [6]. Zhang et al. [7] showed that brand value comes from the asset value as well as the customer value. From the above analysis, brand value evaluation can be carried out based on three perspectives: asset-based perspective, customer-based perspective, and a combination of asset and customerbased perspective. These three kinds of evaluation methods focus on different points.

\section{The Method of Brand Valuation}

\subsection{Brand Value Evaluation Based on Asset Perspective}

Brand asset value is the foundation of brand value evaluation [8]. Specifically, it's to quantify the value of brand asset from the perspective of corporate finance, which means brand value is reflected in the financial benefits obtained by companies from the brand [9]. Based on this, Liu [10] indicated that the market share, excess profits, brand protection, trends and market characteristics as well as the ability of internationalization of the brand are elements that brand valuation must include, and other value elements not related to brand asset can't be contained. So when using a certain method for brand valuation, a major difficulty is to distinguish the benefit of brand asset from that of corporate's other intangible assets. Only stripping out the real contribution created by brand asset, does brand value avoid being overestimated.

There are many brand valuation methods with quantitative indicators under the asset perspective, in which the Interbrand method and the Financial World method show greatest impact. Fu [11] argued that the Interbrand method has a basic assumption: brand value is reflected to ensure that brand owners can get a more stable income in the future. Thus, it is necessary to assess brand value on the basis of the company's future earnings through financial analysis, market analysis and brand analysis. First, use financial analysis to evaluate the residual earnings of a product or a business, which refers to the balance of the future income from the product or business minus the revenue from the tangible assets. Second, clear the impact of brand on the industry of the product or service through market analysis, thus determining how many percentages of residual earnings are created by the brand, so as to calculate the brand's future earnings. Third, take the analysis from ten areas including authenticity, clarity, brand commitment, brand protection, adaptability, consistency, diversity, visibility, relevance and understandability to determine the coefficient of brand strength, then convert the brand strength coefficient to the discount rate of brand's future earnings through an S-shaped curve [11] (the discount rate is used when discounting brand future earnings for the current yield). According to this idea, brand value is calculated as: brand value $=$ future earnings of brand $\times$ brand strength. On the basis of inheriting the advantages of the Interbrand method, the Financial World method develops its own characteristic with the expert assessing brand market performance to obtain the data of brand's earnings. Assessment is first built on the company's sales. The expert judges the average profit margin of industry according to his experience, and calculates the company's operating profit, from which excludes profits that have nothing to do with the brand, in order to get the data of pure profit created by brand. Next, calculate the brand strength coefficient using the Interbrand method. Finally, calculate the brand value with the formula as follows: brand value $=$ brand net profit $\times$ brand strength.

\subsection{Brand Value Evaluation Based on Customer Perspective}

Brand Valuation under the perspective of customers, is to measure the brand's status in their hearts from the de- 
gree of such aspects as their familiarity with the brand, perception of the brand quality, and association of the brand, etc. Yu and Zhao [12] believed that customers are the foundation of brand value, and argued that brand value is "the differential response of customers to enterprise marketing activities in the aspects of cognition, emotion, and behavior intention and behavior”. On this basis, Kim and Kim [13] pointed out that customerbased brand valuation must consider three factors: brand loyalty, perceived quality and brand image. Wang [14] thought besides the joint action of brand loyalty and brand awareness, brand valuation needs to consider the influence of whether the customer to buy on the real value of brand. Researches under customers' perspective provide a basis for the quantitative assessment of brand value.

Brand valuation methods based on the customer perspective with quantitative indicators include the premium method and the loyalty factor method. The principle of the premium method is that by calculating how high an extra price customers are willing to pay when buying a particular brand of product or service to determine the size of the brand value. It includes the following three steps. First of all, through the market research to confirm the price of overflow, namely the extra price that customers are willing to pay for the purchase of a branded goods or services compared with buying a non-branded product or service. And then calculate the excess profit by multiplying the price with the current sales of the branded product or service. Finally, get the brand value with the excess profits divided by the industry's average profit margin of the branded product or service, which is calculated as follows: brand value $=$ the premium $\times$ sales/average profit margin. On the basis of consideration of the premium as well as sales of a branded product or service, Fan and Leng [15] added the element of customer loyalty to further improve the brand valuation method. They believed that brand value embodies in that the brand can increase corporate benefits in the future, which depends on a broad customer loyalty. To this end, they used the "loyalty factor" to represent the proportion of customers deciding to start buying or repeat buying the branded product in the future to all the target customers, with the help of the customer's brand loyalty and brand attractiveness to assess the brand value. The calculation formula is: brand value = theoretical target customer base $\times$ loyalty factor $\times$ cycle purchases $\times$ (unit product price - unit unbranded product price) $\times$ numbers of cycle within the time limit.

\subsection{Brand Value Evaluation Based on a Comprehensive Perspective}

Brand value evaluation based on a comprehensive perspective exhibits establishing the link between brand asset and customers, considering the value brought to the enterprise and the customer at the same time by the brand. Hence, Yoo and Donthu [16] pointed out that brand asset value based on the customer can be measured through three dimensions including brand loyalty, perceived quality and brand awareness/association. Washburn and Plank [17] built the evaluation scale of brand equity value from the view of the customer. In addition, He and Zhao [18] found that brand value assessment can be carried out by three factors seven dimensions, in which these three factors are common factor, basic common factor and special factor. Common factor includes four dimensions: brand loyalty, brand image, entrepreneur image and brand support. Basic common factor includes two dimensions: brand innovation and brand tenacity, and special factor includes a dimension reflecting the industry. In summary, these results enrich the study of brand valuation method under the comprehensive perspective.

More well-known brand valuation methods based on a comprehensive perspective include the ten elements model of brand equity and the model of customer-based brand equity. Aaker believes, brand value is "a group of assets and liabilities associated with the name and symbol of a brand, which can increase or reduce the value to the company or the customer caused by a product or services", and takes five specific dimensions 10 indicators (that is, ten elements) for brand valuation (as shown in Table 1). The brand value under this model is calculated as: brand value $=($ price advantage + satisfaction/loyalty $)+($ perceived quality + leading brand/popularity $)+$ (perceived value + brand personality + organization association) + brand awareness + (market prices and distribution channels + market share). In the same period when Aaker proposed the ten elements model of brand equity, Keller also put forward another influential method of brand valuation. The core of this approach is how to measure brand equity value from the customer level, referred to as CBBE model (as shown in Figure 1). Among them, the significance means the extent of difficulty and the frequency that the brand can be identified in a variety of situations by the customer. The performance and image are used to measure the degree of customer's perception of brand connotation from the specific (functional) and abstract angle respectively. The evaluation and perception measure the extent of customer's reflexion of the brand, the former of which refers to the customer's view of the brand, and the latter is perceptual behavior of the customer to the brand, such as enthusiasm, 
Table 1. Brand equity ten elements.

\begin{tabular}{cc}
\hline Core dimensions & Evaluation factors \\
Brand loyalty & Price advantage \\
Brand perception & Satisfaction/loyalty \\
& Perceived quality \\
Brand association & Leading brand/popularity \\
& Perceived value \\
Brand awareness & Brand personality \\
Brand market situation & Organization association \\
& Brand awareness \\
\hline
\end{tabular}

The chart source: according to the relevant literature review.

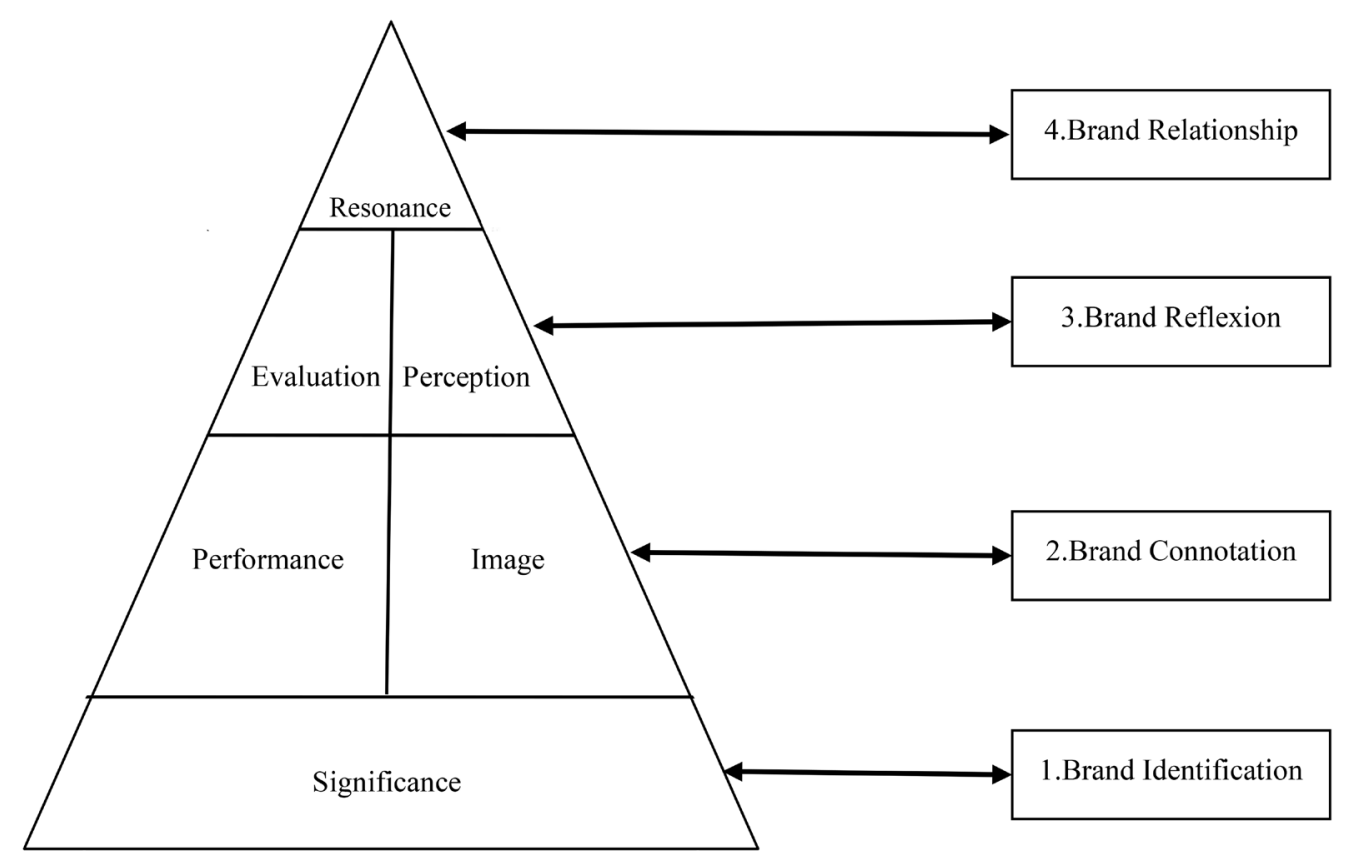

Figure 1. CBBE model. The chart source: according to the reference drawn in this paper.

self-esteem. The resonance is to measure the strength of the relationship between the customer and the brand. Therefore, the brand value under the CBBE model is calculated as: brand value $=$ brand significance + (brand performance + brand image) + (brand evaluation + brand feeling) + brand resonance.

\section{The Enlightenment to Brand Value Evaluation Practice of Chinese Enterprise}

In the past few years, brand valuation practice of Chinese enterprise has got some developments. However, it is still in its infancy, and there are many urgent problems need to consider when applying the above methods. In the first place, the government-led "famous brand" assessment activities have appeared in the reality. In order to make their own corporate brands rank well, candidates often bribe related personnel who are responsible for brand valuation work, causing the evaluation results to loss their objectivity. In addition, although brand valuation can be carried through based on asset perspective, customer perspective and a comprehensive perspective, these methods under each perspective are not applicable to all types of brands. Their scopes of application are shown in Table 2. 
Table 2. Various brand value evaluation methods.

\begin{tabular}{|c|c|c|c|}
\hline Dimension & Method name & Calculation expression & Scope of application \\
\hline \multirow{2}{*}{$\begin{array}{l}\text { Based on asset } \\
\text { perspective }\end{array}$} & The Interbrand method & $\begin{array}{l}\text { Brand value }=\text { future earnings } \\
\text { of brand } \times \text { brand strength }\end{array}$ & $\begin{array}{l}\text { Be used in any product category or } \\
\text { brand, especially in such market } \\
\text { behaviors as brand acquisitions, } \\
\text { mergers or leasing [20]. However, } \\
\text { when the range of product's brand } \\
\text { radiation is narrow, it does not work. }\end{array}$ \\
\hline & $\begin{array}{l}\text { The Financial } \\
\text { World method }\end{array}$ & $\begin{array}{l}\text { Brand value }=\text { brand net } \\
\text { profit } \times \text { brand strength }\end{array}$ & $\begin{array}{l}\text { Be used in any product category or } \\
\text { brand, especially in such market } \\
\text { behaviors as brand acquisitions, } \\
\text { mergers or leasing [20]. However, } \\
\text { when the range of product's brand } \\
\text { radiation is narrow, it does not work. }\end{array}$ \\
\hline \multirow[b]{2}{*}{$\begin{array}{l}\text { Based on } \\
\text { customer } \\
\text { perspective }\end{array}$} & $\begin{array}{l}\text { The premium } \\
\text { method }\end{array}$ & $\begin{array}{l}\text { Brand value }=\text { the premium } \times \\
\text { sales/average profit margin }\end{array}$ & $\begin{array}{l}\text { More suitable for products that the } \\
\text { customer is relatively familiar with. }\end{array}$ \\
\hline & $\begin{array}{l}\text { The loyalty } \\
\text { factor method }\end{array}$ & $\begin{array}{l}\text { Brand value }=\text { theoretical target customer } \\
\text { base } \times \text { loyalty factor } \times \text { cycle purchases } \times \text { (unit } \\
\text { product price }- \text { unit unbranded product price) } \\
\times \text { numbers of cycle within the time limit }\end{array}$ & $\begin{array}{l}\text { For products frequently purchased, but } \\
\text { not for consumer durables with a long } \\
\text { period to repeat shopping [15]. }\end{array}$ \\
\hline \multirow[t]{2}{*}{$\begin{array}{l}\text { Based on a } \\
\text { comprehensive } \\
\text { perspective }\end{array}$} & $\begin{array}{l}\text { The ten elements } \\
\text { model of brand equity }\end{array}$ & $\begin{array}{l}\text { Brand value }=\text { (price advantage }+ \text { satisfaction/ } \\
\text { loyalty })+(\text { perceived quality }+ \text { leading brand/ } \\
\text { popularity })+(\text { perceived value }+ \text { brand } \\
\text { personality + organization association })+ \text { brand } \\
\text { awareness + (market prices and distribution } \\
\text { channels + market share })\end{array}$ & $\begin{array}{l}\text { Not only for researches of continuity, } \\
\text { but also for customised research; } \\
\text { for a specific industry, appropriate } \\
\text { adjustments are made for indicators } \\
\text { to better adapt to the characteristics } \\
\text { of the industry [20]. }\end{array}$ \\
\hline & The CBBE model & $\begin{array}{c}\text { Brand value }=\text { brand significance }+ \text { (brand } \\
\text { performance }+ \text { brand image })+(\text { brand } \\
\text { evaluation }+ \text { brand feeling })+ \text { brand resonance }\end{array}$ & $\begin{array}{l}\text { More suitable for products that the } \\
\text { customer is relatively familiar with. }\end{array}$ \\
\hline
\end{tabular}

The chart source: according to the relevant literature review.

Moreover, each brand valuation method is more or less flawed. Lu Juan [19] argued that congenital deficiencies exists in brand valuation, and no matter what kind of method is used to assess brand value, the result could only guarantee relatively reasonable but not absolute accurate. Therefore, it demands a rational view of brand valuation methods under different perspectives. To begin with, evaluation methods from the asset perspective quantify the value of the brand with financial indicators, such as brand revenues or brand profits, which are not only in line with the principle of measurability of valuation, but also to facilitate their applications in practice. However, they ignore the impact of customers on brand value. More importantly, they do not take the special nature of Chinese enterprise market into account. At present, the enterprise market in China has not yet achieved the situation of full competition, individual industry even gives its priority to monopolistic market, resulting in the flow of profits between industries is uneven. The Interbrand method, while trying to use the "brand effect index" to account for differences in the role of brands in different industries, but "brand effect index" is subjective [11], thus fails to objectively reflect the fact of Chinese enterprise market.

Brand value evaluation from customers' perspective, helps businesses obtain more real data of brand value, and clears the source of each part of value. However, brand value assessment must consider the case of brand creating value in the future, which is principle of perspectiveness. The corporate assesses brand value through the perspective of customers, the resulting data from which to a large extent only reflects the value of the brand at this stage. The loyalty factor method tries to consider profitability cases of the brand in the future using the "loyalty factor", but due to the uncertainty between the purchase intention and the actual purchase behavior, as well as the possibility and quantity of purchase for different customers being not the same [15], this method also just gets data of the brand value at present.

Finally, brand valuation method of an integrated perspective, like the ten elements model of brand equity, gains the result of a comprehensive and close to the fact when assessing the brand value. It takes these factors into account from both the brand asset level, such as brand's market share, and the customer level, such as customer's satisfaction or loyalty to the brand. However, because it involves too many measurement indexes, thus increasing the difficulty of its usage in practice. Comprehensive analysis, the government should involve as less 
as possible or even withdraw from the field of brand valuation, so that it can be carried out in accordance with the market mechanism. Meanwhile, when taking brand valuation, Chinese enterprises should choose a more appropriate method to obtain an objective and accurate evaluation result according to their own industry characteristics.

\section{Conclusion}

This paper explains the specific meaning of brand value, which is reflected in the brand asset value, the relationship value between the customer and the brand and the comprehensive value of both the asset and the customer. On this basis, it sorts out the relevant literature on brand valuation method from a different perspective, and proposes several enlightenments for brand valuation practices of Chinese enterprises. It can be said, this article provides an idea to solve the problem that there isn't a unified point of view on the method of brand value evaluation in the theoretical circle. Moreover, since the mergers and acquisitions between different brands are in vogue at present, how to evaluate the brand value objectively and comprehensively is a problem of the industry. This article takes brand valuation based on asset perspective, customer perspective, and a comprehensive perspective, to make a very good response for this problem.

\section{References}

[1] Yoo, B., Donthu, N. and Lee, S. (2000) An Examination of Selected Marketing Mix Elements and Brand Equity. Journal of the Academy of Marketing Science, 28, 195-211. http://dx.doi.org/10.1177/0092070300282002

[2] Esteban-Bravo, M. and Lado, N. (2011) Brand Value in Horizontal Alliances: The Case of Twin-Cars. Journal of the Operational Research Society, 62, 1533-1542. http://dx.doi.org/10.1057/jors.2010.112

[3] Tom, C., Tim K. and Jack, M. (1999) Valuation. Encyclopedia of China Press, Beijing.

[4] Keller, K.L. (1993) Conceptualizing, Measuring, and Managing Customer-Based Brand Equity. The Journal of Marketing, 57, 1-22. http://dx.doi.org/10.2307/1252054

[5] Keller, K.L., Heckler, S.E. and Houston, M.J. (1998) The Effects of Brand Name Suggestiveness on Advertising Recall. The Journal of Marketing, 61, 48-57. http://dx.doi.org/10.2307/1251802

[6] Paul, S.B. and Yin, Y. (2000) The Power of the Brand. CITIC Press, Beijing.

[7] Zhang, Y., Zhang, R. and Liu, J.P. (2010) Review on Sources and Its Theories of Brand Value. Forecasting, 29, 74-80.

[8] Goldfarb, A., Lu, Q. and Moorthy, S. (2009) Measuring Brand Value in an Equilibrium Framework. Marketing Science, 28, 69-86. http://dx.doi.org/10.1287/mksc.1080.0376

[9] Schultz, D.E. and Schultz, H.F. (2003) Brand Babble: Sense and Nonsense about Branding. South-Western Educational Pub, Cincinnati Ohio.

[10] Liu, E.K. (1997) Talk about the Corporate Brand Evaluation Methods from the Elements of Brand Value. Economic Forum, 1, 17-19.

[11] Fu, G.Q. (1999) A Review of Brand Valuation Method of Interbrand. Foreign Economics \& Management, 37-41.

[12] Yu, C.L. and Zhao, P. (2003) Brand Asset and the Interpretation of the Related Concentsin Evaluating This Brand Asset. Nankai Business Review, 10-13.

[13] Kim, H.-B. and Kim, W.G. (2005) The Relationship between Brand Equity and Firms’ Performance in Luxury Hotels and Chain Restaurants. Tourism Management, 26, 549-560. http://dx.doi.org/10.1016/j.tourman.2004.03.010

[14] Wang, J.F. (2004) A Research in Brand Value. Economic Survey, 120-122.

[15] Fan, X.C. and Leng, Y. (2000) The Loyalty Factor Method of Brand Valuation. Scientific Management Research, 18, 50-56.

[16] Yoo, B. and Donthu, N. (2001) Developing and Validating a Multidimensional Consumer-Based Brand Equity Scale. Journal of Business Research, 52, 1-14. http://dx.doi.org/10.1016/S0148-2963(99)00098-3

[17] Washburn, J.H. and Plank, R.E. (2002) Measuring Brand Equity: An Evaluation of a Consumer-Based Brand Equity Scale. Journal of Marketing Theory and Practice, 10, 46-61.

[18] He, Z.Y. and Zhao, Z.B. (2005) Research on the Common Factors of Consumer-Based Brand Equity. Finance and Economics, 75-80.

[19] Lu, J. (2001) A Review of Brand Equity Valuation Method. Statistical Research, 34-37.

[20] Lu, T.H. (2002) Measurement of Brand Equity: Pattern and Perspective. Journal of Sun Yatsen University (Social Science Edition), 44, 88-97. 
Scientific Research Publishing (SCIRP) is one of the largest Open Access journal publishers. It is currently publishing more than 200 open access, online, peer-reviewed journals covering a wide range of academic disciplines. SCIRP serves the worldwide academic communities and contributes to the progress and application of science with its publication.

Other selected journals from SCIRP are listed as below. Submit your manuscript to us via either submit@scirp.org or Online Submission Portal.
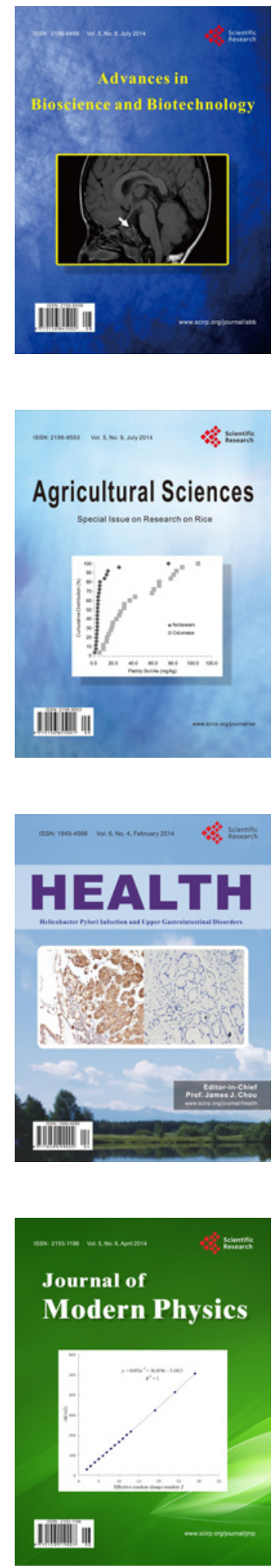
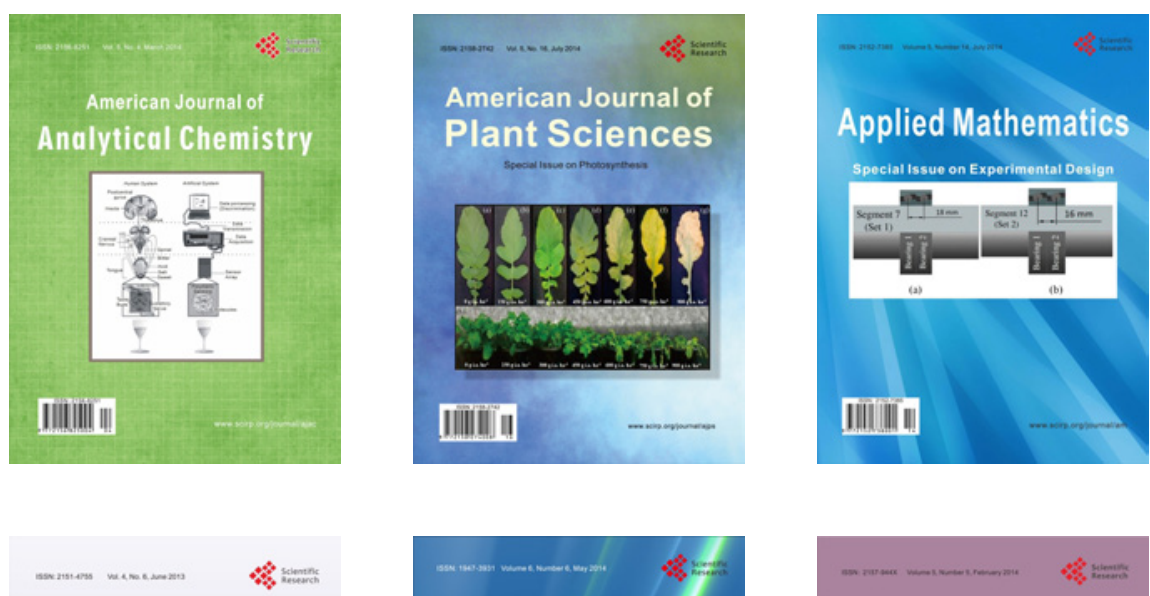

Creative Education
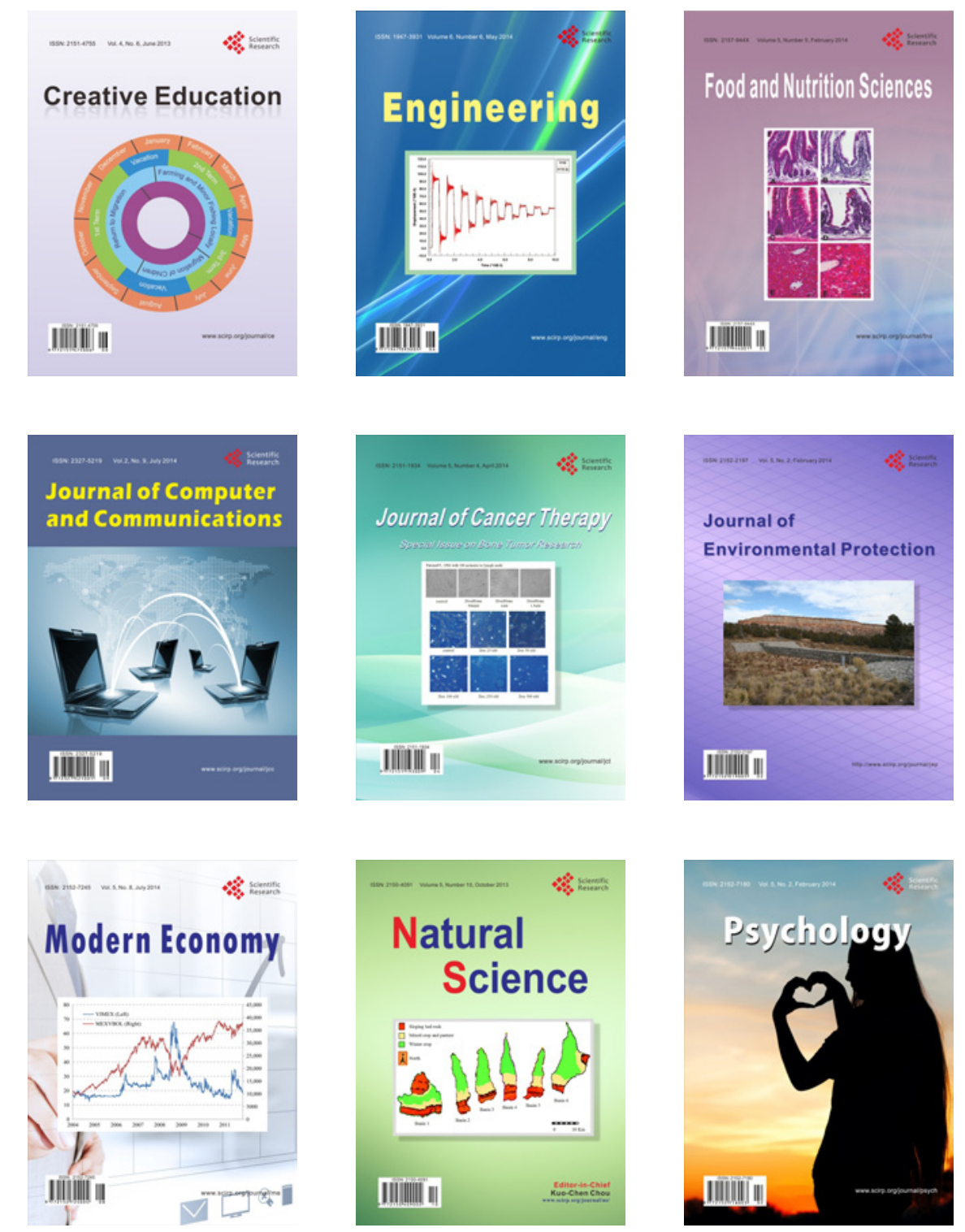